\title{
Effects of the nitrification inhibitor DMPP on soil bacterial community in a Cambisol in northeast China
}

\author{
X.X. Dong ${ }^{1,3}$, L.L. Zhang ${ }^{1}$, Z.J. Wu ${ }^{1 *}$, D.P. Li ${ }^{1}$, Z.C. Shang ${ }^{2}$, and P. Gong ${ }^{1,3}$ \\ ${ }^{1}$ Instituite of Applied Ecology, Chinese Academy of Sciences, P. O. Box 417, Shenyang, 110016, China. ${ }^{2}$ Shanghai Research \\ Institute of Chemical Industry, Shanghai, 200062, China. ${ }^{3}$ Graduate School of the Chinese Academy of Sciences, Beijing 100039, \\ China. "Corresponding author: wuzjchina@hotmail.com
}

\begin{abstract}
A long-term experimental site was built to study effects of the nitrification inhibitor 3, 4-dimethylpyrazole phosphate (DMPP) on a bacterial population's diversity and activity in a Cambisol in northern China. Treatments included no fertilization (CK), application of urea alone (U), and application of urea plus DMPP (UD). The annual application rate for the urea was $180 \mathrm{~kg} \mathrm{~N} \mathrm{ha}^{-1}$, and that of the DMPP was $1.8 \mathrm{~kg} \mathrm{ha}^{-1}$. The diversity and composition of the overall soil bacterial community were analyzed using pyrosequencing, and the abundances of ammonia-oxidizing bacteria $(\mathrm{AOB})$ and ammonia-oxidizing archaea (AOA) were analyzed using a real-time polymerase chain reaction (RT-PCR) assay. The dominant phyla were Proteobacteria, Acidobacteria, Actinobacteria, Bacteroidetes, Gemmatimonadetes, Chloroflexi, Firmicutes, and Planctomycetes in all of the samples. However, compared with treatment $\mathrm{U}$, the relative abundance and identities of the dominant phyla that were increased in treatment UD were more similar to those of the CK treatment. DMPP significantly reduced the targeted ammonia oxidizing bacterial abundance, and the soil potential nitrification rate had a significant positive correlation with the amo $A$ gene copy number of the AOB $(r=0.685, n=9, p<0.05)$ but not of the AOA. The results suggested that long-term application of DMPP to this agricultural soil was relatively beneficial for both urea application and soil bacterial ecosystem reversion.
\end{abstract}

Keywords: Nitrification inhibitor, soil total bacteria, ammonium-oxidizing bacteria, ammonium-oxidizing archaea, long-term experiment 


\section{Introduction}

Many studies have indicated that nitrification inhibitors can improve the use efficiencies of urea- and ammonium-based $\mathrm{N}$ fertilizers and can mitigate soil nitrate leaching and $\mathrm{NxO}$ emission by retarding soil nitrification (Linzmeier et al., 2001; Di and Cameron, 2002; Hatch et al., 2005; Zaman et al., 2009; Chen et al., 2010). In recent years, a new nitrification inhibitor, DMPP, has caused widespread concern among an increasingly wide range of people. DMPP's advantages include lower application rates, greater efficiency, and lower water solubility compared with dicyandiamide (DCD), and application of DMPP-containing fertilizers has been shown to improve yields (Weiske et al., 2001; Zerulla et al, 2001). DMPP delays bacterial oxidation of $\mathrm{NH}_{4}^{+}$to $\mathrm{NO}_{2}^{-}$(the first and rate-limiting step of soil nitrification) by depressing the activities of Nitrosomas bacteria in soil. Previously, autotrophic ammoniaoxidizing bacteria (AOB) were considered to be the most important contributors to ammonia oxidation. In addition to $\mathrm{AOB}$, soil ammonia-oxidizing archaea (AOA) may be important actors in the nitrogen cycles in low-nutrient and low-pH environments (Erguder et al., 2009), and a trade-off between the AOB, AOA, and other soil microbial populations could potentially have existed after the application of nitrification inhibitors. Short-term incubation tests (Kleineidam et al., 2011; Di and Cameron, 2011) showed decreased abundances of AOB but not of AOA as measured by the copy numbers of their amoA genes after the application of DMPP. However, little information is available concerning the abundances of $\mathrm{AOB}$ and AOA in soils treated with DMPP during long-term experiments. In addition, few studies have examined the effects of DMPP on total soil bacteria.

Loamy brown meadow soil (cambisol in the FAO taxonomy) is an important agricultural soil in northern China and covers approximately $10.2 \%$ of the agricultural land in China. Consumption of urea fertilizer for agricultural production on this soil is increasing rapidly, and the application of DMPP to this soil has been practiced for approximately seven years.
In the present study, 0 - to 20 -cm-depth soil samples were collected from a long-term experimental site in the Liaoning Province of Northeast China, and pyrosequencing and real-time PCR techniques were adopted to analyze the abundances and diversities of targeted and total soil bacteria. In addition, the soil's potential nitrification rate was measured to determine the activities of the soil AOB and AOA with the goal of evaluating the microbiological effects of the long-term application of DMPP to a Cambisol.

\section{Materials and Methods}

\subsection{Experiment site}

The site was located at the Shenyang Ecological Experimental Station $\left(41^{\circ} 32^{\prime} \mathrm{N}, 123^{\circ} 23^{\prime} \mathrm{E}\right)$ of the Chinese Academy of Sciences in Liaoning Province in northeast China. The site was established in 2004 and has a temperate, semi-humid continental climate with a mean annual temperature of $7.5^{\circ} \mathrm{C}$ and annual precipitation of $680 \mathrm{~mm}$. The soil type according to the FAO taxonomy (FAO soil classification) is a Cambisol, and its basic physical and chemical characteristics are listed in Table 1.

\subsection{Experimental design}

Three treatments with three replicates for each were used, i.e., no fertilization (CK), urea fertilization (U), and urea fertilization + nitrification inhibitor DMPP (UD). Each plot had an area of $3 \mathrm{~m} \times 10 \mathrm{~m}$ and was planted with maize in May every year. The fertilizers $\mathrm{N}, \mathrm{P}_{2} \mathrm{O}_{5}$, and $\mathrm{K}_{2} \mathrm{O}$ were applied at rates of 180,138 , and $150 \mathrm{~kg} \mathrm{ha}^{-1}$ year $^{-1}$ in the forms of urea, triple superphosphate, and potassium chloride, respectively. DMPP (purity $\geq 97 \%$, BASF) was applied at a rate of $1.8 \mathrm{~kg} \mathrm{ha}^{-1}$ year ${ }^{-1}$. The fertilizers were fully mixed with DMPP and basally applied. 
Table 1. Soil properties for different fertilizer regimes in a long-term soil-inhibitor experiment

\begin{tabular}{llllll} 
Treatment & $\mathrm{pH}^{\mathrm{a}}$ & $\begin{array}{c}\mathrm{C}_{\mathrm{tot}} \mathrm{a}^{2} \\
(\% \mathrm{of} \mathrm{dw})\end{array}$ & $\begin{array}{l}\mathrm{N}_{\mathrm{tot}}^{\mathrm{a}} \\
(\% \mathrm{of} \mathrm{dw})\end{array}$ & $\mathrm{C}: \mathrm{N}$ & Soil moisture \\
& & & & \\
\hline $\mathrm{CK}$ & $5.7(0.06) \mathrm{b}$ & $1.11(0.02) \mathrm{a}$ & $0.10(0.01) \mathrm{b}$ & $10.7(0.24) \mathrm{a}$ & $20.1(0.65) \mathrm{a}$ \\
$\mathrm{U}$ & $4.7(0.09) \mathrm{c}$ & $1.14(0.04) \mathrm{a}$ & $0.18(0.02) \mathrm{a}$ & $6.5(0.79) \mathrm{b}$ & $20.5(0.48) \mathrm{a}$ \\
$\mathrm{UD}$ & $6.6(0.36) \mathrm{a}$ & $1.09(0.03) \mathrm{a}$ & $0.15(0.01) \mathrm{a}$ & $7.7(0.85) \mathrm{b}$ & $20.1(0.93) \mathrm{a}$
\end{tabular}

dw, dry weight; Tot-C, total soil carbon; Tot-N, total soil nitrogen.

${ }^{a}$ When the experimental site was established in 2004, the soil $\mathrm{pH}$ was 5.5 , and the total organic $\mathrm{C}$ and total $\mathrm{N}$ were $1.3 \%$ and $0.17 \%$ of the soil dry weight, respectively. Values are the mean \pm standard deviation of three replicates. Different letters following the values within a column represent significant differences at the 5\% level (U, urea; UD, urea + DMPP).

\subsection{Soil sampling}

Soil samples $(0-20 \mathrm{~cm})$ were collected from each replicate plot during June 2010. Strong microbial activity occurred during this period. Five soil cores (approx. $5 \mathrm{~cm}$ diameter) were collected from each plot and mixed into one composite sample ( $700 \mathrm{~g})$. Each sample was divided into three portions: The first portion was stored at $4{ }^{\circ} \mathrm{C}$ for determinations of the moisture content and potential nitrification rate. The second portion was stored at $-80{ }^{\circ} \mathrm{C}$ for DNA extraction. The third portion was air-dried for analyses of total soil $\mathrm{C}$ and $\mathrm{N}$.

\subsection{Chemical analysis}

The soil $\mathrm{pH}_{(\mathrm{H} 2 \mathrm{O})}$ was determined using a $\mathrm{pH}$ meter, and the soil total $\mathrm{N}$ content was determined using an Elemental Analyzer (Vario EL III, Germany). The soil $\mathrm{NH}_{4}^{+}$and $\mathrm{NO}_{3}^{-}$concentrations were measured using the method of Keeney (1982): $5 \mathrm{~g}$ fresh soil was shakenwith a $2.0 \mathrm{M} \mathrm{KCl}$ solution for $1 \mathrm{~h}$ and then filtered. The filtrate was immediately analyzed for $\mathrm{NH}_{4}^{+}$and $\mathrm{NO}_{3}^{-}$ using a Continuous Flow Analyzer (AA III, Germany).

\subsection{Soil potential nitrification rate}

The potential nitrification rate was measured following the Kurola et al. method with slight modifications. A 5-g soil sample (stored at $4{ }^{\circ} \mathrm{C}$ ) was mixed with an ammonium sulfate and sodium chlorate solution. One portion of the soil was incubated for $5 \mathrm{~h}$ on a rotatory, shaker, and another portion was stored at $-20{ }^{\circ} \mathrm{C}$ for 5 $\mathrm{h}$ and served as a control. At the end of the incubation, the soil $\mathrm{NO}_{2}^{-}-\mathrm{N}$ was extracted, and $5 \mathrm{ml}$ of the extract was added to $3 \mathrm{~mL}$ ammonium chloride buffer and 2 $\mathrm{mL}$ developer. After color development, the $\mathrm{NO}_{2}^{-}-\mathrm{N}$ concentration was determined using an ultraviolet spectrophotometer. The soil potential nitrification rate (PNR) was calculated using the following formula: 
580

PNR $\left(\mu \mathrm{g} \mathrm{N} \cdot \mathrm{g}^{-1} \mathrm{dw} \cdot 5 \mathrm{~h}\right)=(\mathrm{S} * 10-\mathrm{C} * 10) * 25.12 / 5$,

where S (mg N), $10(\mathrm{~mL}), \mathrm{C}(\mathrm{mg} \mathrm{N}), 25.12(\mathrm{~mL})$, and $5(\mathrm{~g})$ represent the $\mathrm{NO}_{2}^{-}-\mathrm{N}$ concentration in the incubated sample, the total volume of the extract used for the determination, the $\mathrm{NO}_{2}^{-}-\mathrm{N}$ concentration of the control, and the soil dry mass, respectively.

\subsection{DNA extraction}

DNA was extracted from $0.5 \mathrm{~g}$ (fresh weight) soil using the FastDNA Spin Kit for soil (Qbiogene, Carlsbad, CA, USA) according to the manufacturer's instructions. The extracted DNA was evaluated using $1 \%$ agarose gel electrophoresis and stored at $-20^{\circ} \mathrm{C}$ before amplification.

\subsection{Abundance of bacteria}

The abundance of bacteria was determined using quantitative PCR using the 7500 Fast Real-Time PCR Instrument (Applied Biosystems, America) with the SYBR $^{\circledR}$ Premix Ex Taq ${ }^{\mathrm{TM}}$ (TaKaRa, Japan) following the manufacturer's protocol. PCR cycle conditions for the amo $A$ gene consisted of $95^{\circ} \mathrm{C}$ for $5 \mathrm{~min}$, followed by 40 cycles of $94{ }^{\circ} \mathrm{C}$ for $10 \mathrm{sec}, 53{ }^{\circ} \mathrm{C}$ for $15 \mathrm{sec}$, and $72{ }^{\circ} \mathrm{C}$ for $45 \mathrm{sec}$. Bacterial RT-PCR cycle conditions consisted of $95{ }^{\circ} \mathrm{C}$ for $5 \mathrm{~min}$, followed by 35 cycles of $94{ }^{\circ} \mathrm{C}$ for $10 \mathrm{sec}$ and $55{ }^{\circ} \mathrm{C}$ for $30 \mathrm{sec}$, and $72{ }^{\circ} \mathrm{C}$ for $45 \mathrm{sec}$. Each reaction was performed in a $20-\mu \mathrm{L}$ volume containing $10 \mu \mathrm{L} \mathrm{SYBR}^{\circledR}$ Premix EX Taqll, 0.4 $\mu \mathrm{M}$ each primer (Table 2), $0.4 \mu \mathrm{L}$ ROX Reference Dye and $20 \mathrm{ng}$ template DNA (10-fold diluted template DNA). All PCR reaction sets included negative controls (without the template DNA) to test for possible non-specific amplification. A DNA-meltingcurve analysis was used to verify the specificities of the PCR reaction products after amplification by continuously monitoring fluorescence during warming at a temperature transition rate of $0.1{ }^{\circ} \mathrm{C} / \mathrm{s}$ from 60 ${ }^{\circ} \mathrm{C}$ to $95{ }^{\circ} \mathrm{C}$. Standard curves were constructed using serial dilutions of linearized plasmids containing the target genes, and the curves were linear for $10^{2}$ to $10^{8}$ gene copies. The plasmids used were constructed as follows. Standard PCR products were purified using a PCR cleanup kit (Axygen) and cloned into the pGEM-T Easy Vector (Promega, Madison, WI). The resulting ligation mix was transformed into Escherichia coli JM109 competent cells (Promega) following the manufacturer's instructions. Each plasmid DNA concentration was determined using a QubitTM fluorometer (Invitrogen NZ), and the copy number of the target gene was calculated directly from the concentration of the extracted plasmid DNA. For each gene, the amplification efficiency was $95-100 \%$, the $\mathrm{R}^{2}$ value was greater than 0.99 , and no signal was observed in the negative controls.

\subsection{Taxonomic composition of the soil bacterial community}

Universal 16S rRNA gene primers (Escherichia coli positions 8 to 533) (Table 2) were chosen for amplification and subsequent pyrosequencing of the PCR products. The PCR mixture $(50 \mu 1$ final volume) contained $10 \mu \mathrm{l} 5 \mathrm{X}$ reaction buffer (TransStart TM FastPfu Buffer, TransGen Biotech), $<100$ ng soil DNA, $0.4 \mathrm{mM}$ each primer, 0.5 U Pfu polymerase (TransStart ${ }^{\text {TM }}$ FastPfu DNA Polymerase, TransGen Biotech), and $2.5 \mathrm{mM}$ dNTPs. For each sample, three independent PCR reactions were performed using an MG96 +Thermal Cycler (LongGene Scientific Instruments Co., Ltd). The PCR conditions were as follows: 94 ${ }^{\circ} \mathrm{C}$ for $5 \mathrm{~min}, 30$ cycles of denaturation $\left(94{ }^{\circ} \mathrm{C}\right.$ for 1 $\mathrm{min})$, annealing $\left(55^{\circ} \mathrm{C}\right.$ for $\left.40 \mathrm{sec}\right)$, and extension (72 ${ }^{\circ} \mathrm{C}$ for $2 \mathrm{~min}$ ), followed by a final elongation $\left(72{ }^{\circ} \mathrm{C}\right.$ for $10 \mathrm{~min}$ ). The DNA produced was quantified using a TBS-380 Mini-Fluorometer (Promega Corporation, CA, USA), and the sequences of the partial 16S rRNA genes were determined using the Roche GS-FLX 454 pyrosequencer (Roche, Mannheim, Germany).

\subsection{Statistical analysis}

All results were calculated based on oven-dried (105 ${ }^{\circ} \mathrm{C}$ ) weights of the samples. Pyrosequencing-derived data were analyzed using the MOTHUR program (http://www.mothur.org), and DNA distance matrices 
were calculated using the DNADIST program in PHYLIP (version 3.68). These matrices were used to assess the numbers of operational taxonomic units (OTUs) detected at sequence divergences of $3 \%$ (species members share more than 3\% 16S rRNA identity) in our test communities. All other experimental results were statistically analyzed using SPSS 16.0 and one-way analysis of variance (ANOVA) followed by the SNK test.

Table 2. Real-time PCR assay primers

\begin{tabular}{llll}
\hline Primer & Nucleotide sequence (5' -3') $^{\prime}$ & Target gene & Ref. \\
\hline $\begin{array}{l}\text { Pyrosequencing } \\
\text { primers }\end{array}$ & & & \\
$8 \mathrm{~F}$ & AGAGTTTGATCCTGGCTCAG & Bacterial 16S rRNA & Bracker et al., 2003 \\
$533 \mathrm{R}$ & TTACCGCGGCTGCTGGCAC & Bacterial 16S rRNA & Bracker et al., 2003 \\
RT-PCR primers & & & \\
341 & CCTACGGGAGGCAGCAG & Bacterial 16S rRNA & \\
758 & CTACCAGGGTATCTAATCC & Bacterial 16S rRNA & \\
Arch-amoAF & STAATGGTCTGGCTTAGACG & AOA amoA & Francis et al., 2005 \\
Arch-amoAR & GCGGCCATCCATCTGTATGT & AOA amoA & Francis et al., 2005 \\
$1 \mathrm{~F}$ & GGGGTTTCTACTGGTGGT & AOB amoA & Rotthauwe et al., 1997 \\
$2 \mathrm{R}$ & CCCCTCKGSAAAGCCTTCTTC & AOB amoA & Rotthauwe et al., 1997 \\
\hline
\end{tabular}

\section{Results}

\subsection{Soil total bacterial population size}

The abundance of the bacterial 16S rRNA gene, which reflects the size of the total bacterial community, was in the range of $3.18 \times 1010$ to $4.14 \times 1010$ gene copies $\mathrm{g}^{-1}$ dry soil and exhibited little variation among the treatments (Table 3).

\subsection{Phylogenetic diversity and community composition}

The best reproducibility was found when using three replicates, so we used sets of data with three replicates for our analysis. With read lengths of $\geq 150$ base pairs (bp), 17829 high-quality sequences were classified as Bacterial from a total of 21722 reads across all of the samples. The number of Bacterial sequences per sample ranged from 5391 to 6553 , with an average of 5943. Most rarefaction curves reached plateaus after $\sim 5300$ pyrotags were sequenced, indicating that the sampling effort covered almost the full extent of the samples' taxonomic diversities using a genetic distance of 3\% (Figure 1).

Coverage values for all of the treatments were approximately $80 \%$ (data not shown), indicating that the sequencing level could reflect the soil bacterial 
communities' structures. The 17829 classifiable sequences were affiliated with 16 phyla across the entire dataset. The dominant phyla in the CK treatment were Proteobacteria, Acidobacteria, Actinobacteria, Bacteroidetes, Gemmatimonadetes, Chloroflexi, Firmicutes, and Planctomycetes, with their members representing approximately $86.54 \%$ of all of the sequences (Figure 2).
Compared with the CK treatments, Bacteroidetes and Firmicutes in the $U$ treatments were increased by $3.3 \%-1.7 \%$, and Bacteroidetes and Firmicutes in the UD treatments were increased by $2.0 \%-1.2 \%$. In contrast with the $\mathrm{U}$ treatments, which showed relative abundances of most phyla increased by $0.1-0.2 \%$, the UD treatments showed levels similar to those of the CK treatments.

Table 3. Abundance of total soil bacteria and AOB and AOA amoA gene copy numbers quantified by qPCR

\begin{tabular}{llll}
\hline RT-PCR & CK & $\mathrm{U}$ & UD \\
(copy numbers & & & \\
$\mathrm{g}^{1} \mathrm{dw}$ soil ) & & & \\
\hline Total bacteria & $3.65 \mathrm{E}+10(2.35 \mathrm{E}+9) \mathrm{a}$ & $4.14 \mathrm{E}+10(2.76 \mathrm{E}+9) \mathrm{a}$ & $3.18 \mathrm{E}+10(2.52 \mathrm{E}+9) \mathrm{a}$ \\
AOB amoA gene & $1.36 \mathrm{E}+7(3.95 \mathrm{E}+6) \mathrm{b}$ & $9.60 \mathrm{E}+8(1.93 \mathrm{E}+8) \mathrm{a}$ & $1.47 \mathrm{E}+7(3.36 \mathrm{E}+6) \mathrm{b}$ \\
AOA amoA gene & $5.88 \mathrm{E}+8(4.02 \mathrm{E}+7) \mathrm{a}$ & $3.27 \mathrm{E}+8(4.82 \mathrm{E}+7) \mathrm{a}$ & $3.19 \mathrm{E}+8(3.53 \mathrm{E}+7) \mathrm{a}$
\end{tabular}

Values are the mean \pm standard deviation of three replicates. Different letters above the columns with the same symbols represent significant differences at the 5\% level (U, urea; UD, urea + DMPP; dw, dry weight).

\subsection{Abundances of $A O B$ and $A O A$ populations}

In the $\mathrm{CK}$ treatment, the copy number of the AOA amoA gene was far greater than that of the AOB amoA gene, but the AOA amoA gene copy number was not significantly different among the treatments. A significant increase was observed in the copy number of the $\mathrm{AOB}$ amo $A$ gene in treatment $\mathrm{U}$ compared with treatment CK $(p<0.05)$, and the application of DMPP resulted in a significant decrease in the copy number of the AOB amoA gene compared with that of the $\mathrm{U}$ treatment (Table 3).

\subsection{Soil potential nitrification rate}

The soil potential nitrification rate was significantly higher for the U treatment than for the UD and CK treatments $(p<0.05)$, and no significant difference between the UD and CK treatments were noted (Figure 3). Correlation analysis indicated that the soil potential nitrification rate was positively correlated with the copy number of the AOB amoA gene $(\mathrm{r}=0.685, \mathrm{n}=9, p<0.05)$ but not correlated with the copy number of the AOA amoA gene (Table 4). 


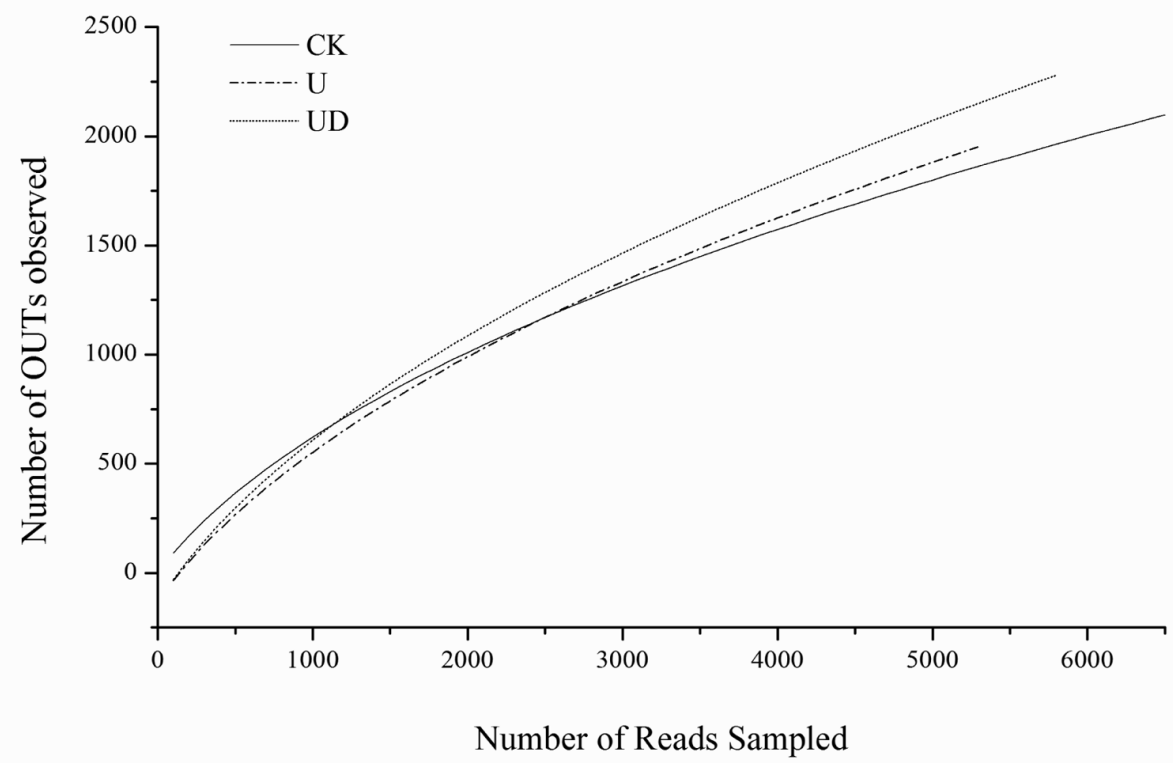

Figure 1. Rarefaction curves indicating the observed numbers of operational taxonomic units (OUTs) at a genetic distance of $3 \%$ in soils subjected to three different treatments (CK, control; U, urea; UD, urea + DMPP).

Table 4. Correlations between the amoA gene copy numbers of AOA and AOB and the soil potential nitrification

\begin{tabular}{llll}
\hline & SPNR & AOA(a) & AOB(a) \\
\hline SPNR & 1 & & \\
AOA(a) & 0.366 & 1 & 1 \\
AOB(a) & $0.685^{*}$ & 0.24 & 1 \\
\hline
\end{tabular}

**The correlation is significant at the 0.05 level (2-tailed), $\mathrm{n}=9$.

SPNR, Soil potential nitrification rate

a, amoA gene copy number 


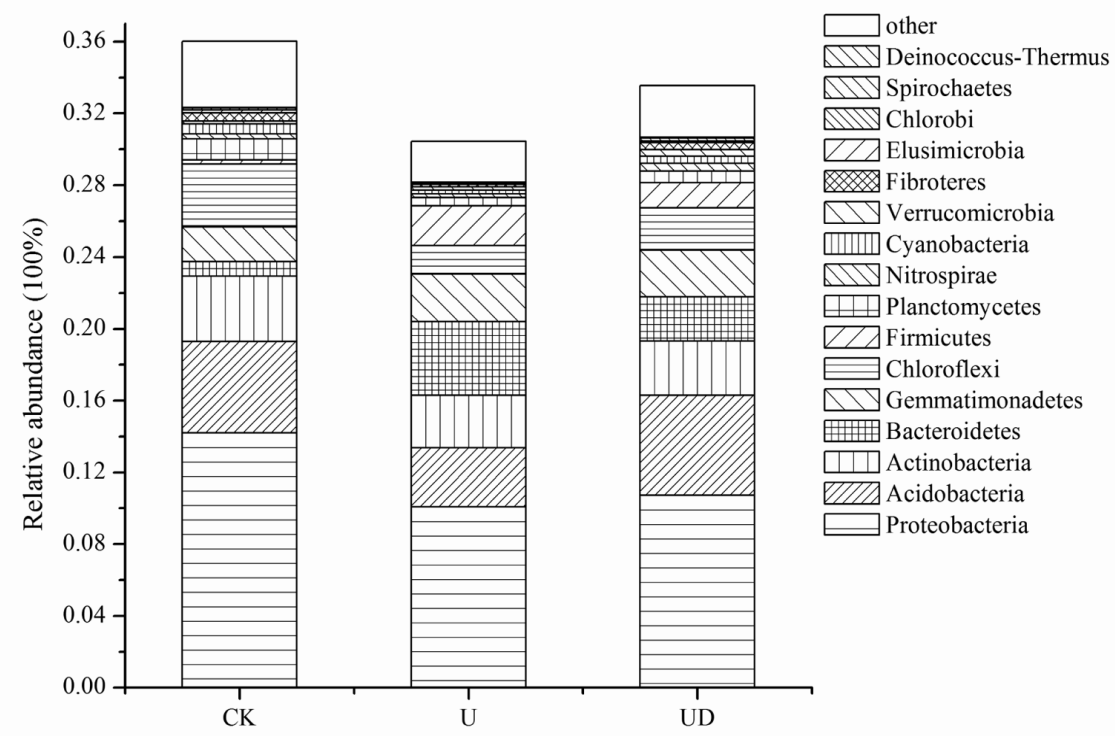

Figure 2. Relative abundances of bacterial phyla in soils recovered from three different treatment plots (CK, control; $\mathrm{U}$, urea; UD, urea + DMPP).

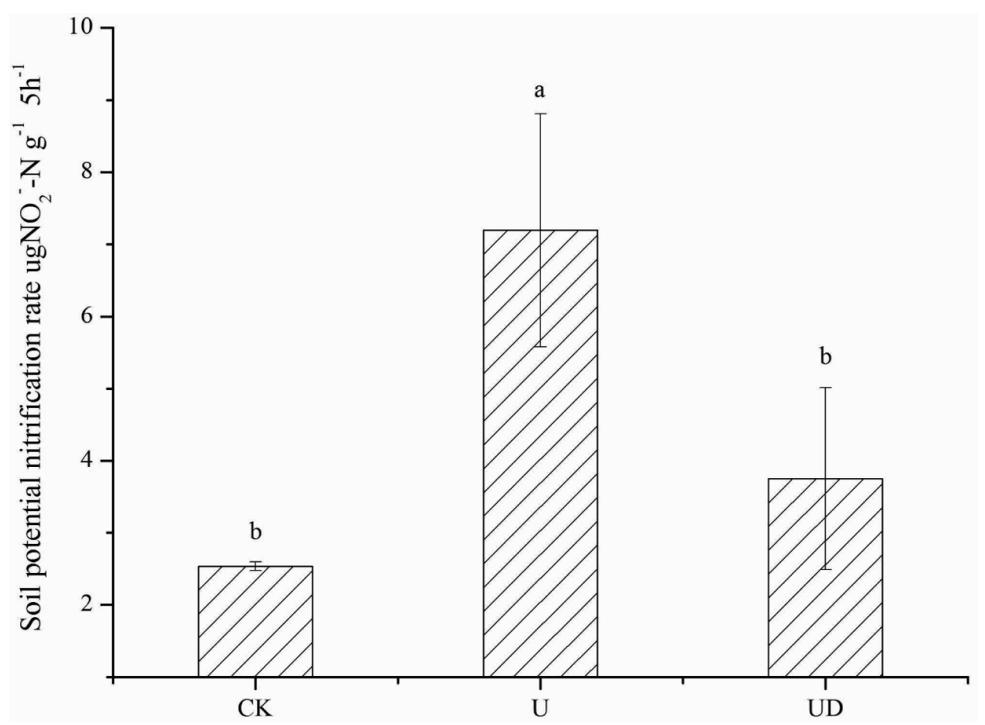

Figure 3. Soil potential nitrification in soils subjected to different long-term treatments. Values are the mean \pm standard deviation of three replicates. Different letters above the columns with the same symbols represent significance at the $5 \%$ level (CK, control; U, urea; UD, urea + DMPP). 


\section{Discussion}

\subsection{Effects of DMPP on soil total bacterial community structure and abundance}

The potential negative effects of the application (particularly the long-term application) of nitrification inhibitors on the soil non-target bacterial community are important to assess because such treatments might impact the biological function of a soil ecosystem. O'Callaghan et al. (2010) indicated that applying urine + DCD had significant effects on soil bacterial microorganisms. Indeed, in the present study, the populations of bacterial phyla in the community exhibited little change among the treatments, although some shifts in the bacterial composition were observed, with 15 phyla found in the controls, 13 phyla in the U treatments, and 16 phyla in the UD treatments. The differences in these results may have been due to shifts in soil $\mathrm{pH}$ caused by addition of urine having strong effects on bacterial diversity and community structure (Fierer and Jackson, 2006; Singh et al., 2009). In the current experiment, the proportions and compositions of various phyla in the urea + DMPP treatment maintained greater diversity in comparison to the urea treatment. In addition, the $\mathrm{pH}$ in the urea + DMPP treatment remained high, at 6.6, in contrast to the other treatments. Several studies have reported that application of urine or urine + a nitrification inhibitor to soil changed microbial community structure (Rooney et al., 2006; Singh et al., 2009; O'Callaghan et al., 2010), but none of these studies has provided particular taxonomic data, and the increases in the numbers of Firmicutes and Bacteroidetes and the reduction in the numbers of Planctomycetes in the urea-treated soils, and Spirochetes was found in the urea + DMPP treatment have not been reported previously.

\subsection{Effects of DMPP on soil $A O A$ and $A O B$ abundances and soil potential nitrification rate}

Many researchers have proposed that the abundant soil AOA should contribute to the nitrogen cycle in agricultural soils. For example, soil nitrate production has been strongly correlated with the abundance of soil AOA (Gubry-Rangina and Prosser, 2010; Chen et al., 2011). In the current study, the abundance of the soil AOA was, indeed, far larger than that of the AOB, but the AOA had no response to the applied urea and DMPP. In contrast, the abundance of soil AOB showed a significant increase under the application of urea and a significant decrease when DMPP was applied. These findings are similar to the results of previous work by Chen et al. (2011), Höfferle et al. (2010), Jia and Conard (2009), and Di et al. (2009a, 2010b) and are in accordance with results showing that the nitrification inhibitors acetylene and DCD had negative effects on soil AOB amoA gene copy number but no effects on soil AOA amoA gene copy number (O'Callaghan et al., 2010; Jia and Conard, 2009; Di et al., 2010a). AOB and AOA prefer different nitrogen conditions for their growth; thus, AOA may not use $\mathrm{NH}_{3}$ as their sole or main energy source and may grow heterotrophically or mixotrophically (Jia and Conard, 2009), whereas AOB prefer higher levels of $\mathrm{NH}_{4}^{+}$.

The soil potential nitrification rate is a measurement of the activity of soil AOB and AOA. Some researchers have reported correlations between soil nitrification rates and bacterial amoA abundances (Jia and Conard, 2009; Di et al., 2009b; He et al., 2007). In the current study, the soil potential nitrification rate was significantly higher in treatment $U$ than in treatments UD and CK and was significantly positively correlated with the abundance of AOB but not correlated with that of AOA. Previous studies have shown that AOA are widely distributed in terrestrial and aquatic systems and potentially represent the most important group of ammonia oxidizers (Francis 2005, Leininger et al. 2006, Nicol et al. 2008, Shen et al. 2008). However, Leininger et al. (2006) research showed that archaeal amoA genes remained high in a low-fertility or no-fertilizer soil, while bacterial amoA genes were reduced significantly, indicating that $\mathrm{AOA}$ are better adapted to soil conditions of low nutrient availability and low pH (Di et al., 2010a; Erguder et al., 2009). These results suggest a positive response of the soil AOB to the applied urea $\mathrm{N}$ and an inhibitory effect of DMPP on the AOB activity. 


\section{Conclusion}

The long-term application of the nitrification inhibitor DMMP to a cambisol in Northeast China had little impact on the abundance of total soil bacteria, but compared with the use of urea alone, the relative abundance and diversity of soil bacterial phyla in the urea+ DMPP treatment were changed and were more similar to the CK treatment. Under the longterm application of this inhibitor, the abundance and activity of the ammonia-oxidizing bacteria in the test soil demonstrated a significant decrease, whereas the abundance and activity of the soil ammonia-oxidizing archaea were not affected. For agriculture-use cambisols, the application of DMPP would benefit the use efficiencies of applied urea- and ammonium-based fertilizers and be a remedial measure for soil microbial ecosystems disturbed by ongoing fertilizer application.

\section{Acknowledgements}

Support from the National Natural Science Foundation of China (41101242) and the National Science \& Technology Pillar Program (2011BAD11B04, 2012BAD14B02) is gratefully acknowledged. We are grateful to the Shenyang Ecological Experimental Station, Chinese Academy of Sciences, for providing the experimental field.

\section{References}

Baker, G.C., Smith, J.J., Cowan, D.A., 2003. Review and re-analysis of domain-specific16S primers. Journal of Microbiological Methods. 55, 541-555.

Chen, D.L., Helen, C.S., Islam, A., Robert, Edis. 2010. Influence of nitrification inhibitors on nitrification and nitrous oxide $\left(\mathrm{N}_{2} \mathrm{O}\right)$ emission from a clay loam soil fertilized with urea. Soil Biology and Biochemistry. 42, 660-664.
Chen, X., Zhang, L.M., Shen, J.P., Wei, W.X., He, J.Z. 2011. Abundance and community structure of ammonia-oxidizing archaea and bacteria in an acid paddy soil. Biology and Fertility Soils. 47, 323331.

Di, H.J., Cameron, K.C., 2002. The use of a nitrification inhibitor, dicyandiamide (DCD), to decrease nitrate leaching and nitrous oxide emissions in a simulated grazed and irrigated grassland. Soil Use and Management. 18, 395-403.

Di, H.J., Cameron, K.C., Shen, J.P., He, J.Z., Winefield, C.S. 2009a. A lysimeter study of nitrate leaching from grazed grassland as affected by a nitrification inhibitor, dicyandiamide, and relationships with ammonia oxidizing bacteria and archaea. Soil Use and Management. 25(4), 454-461.

Di, H.J., Cameron, K.C., Shen, J.P., Winefield, C.S., O'Callaghan, M., Bowatte, S., He, J.Z. 2009b. Nitrification driven by bacteria and not archaea in nitrogen rich grassland soils. Nat Geosci. 2, 621-624.

Di, H.J., Cameron, K.C., Shen, J.P., Winefield, C.S., O'Callaghan, M., Bowatte, S., He, J.Z. 2010a. Ammonia-oxidizing bacteria and archaea grow under contrasting soil nitrogen conditions. FEMS Microbiology Ecology. 72(3), 386-394.

Di, H.J., Cameron, K.C., Sherlock, R.R., Shen, J.P., He, Z.J., Winefield. C.S. 2010b. Nitrous oxide emissions from grazed grassland as affected by a nitrification inhibitor, dicyandiamide, and relationships with ammonia-oxidizing bacteria and archaea. Journal of Soils and Sediments. 10(5), 943-954.

Di, H.J., Cameron, K.C. 2011. Inhibition of ammonium oxidation by a liquid formulation of 3,4-Dimethylpyrazole phosphate (DMPP) compared with a dicyandiamide (DCD) solution in six new Zealand grazed grassland soils. Journal of soils and sediments. 11(6), 1032-1039. 
Erguder, T.H., Boon, N., Wittebolle, L., Marzorati, M., Verstraete, W. 2009. Environmental factors shaping the ecological niches of ammonia oxidizing archaea, FEMS Microbiol Rev. 33,855-869

Fierer, N., Jackson, R.B. 2006. The diversity and biogeography of soil bacterial communities. Proceedings of the National Academy of Sciences of the United States of America, 3789-3793.

Francis, C.A., Roberts, K.J., Beman, J.M. Santoro, A.E., Oakley, B.B. 2005. Ubiquity and diversity of ammonia-oxidizing archaea in water columns and sediments of the ocean. Proceedings of the National Academy of Sciences of the United States of America. 102, 14683-14688.

Gubry-Rangina, C., Nicol, G.W., Prosser, J.I. 2010. Archaea rather than bacteria control nitrification in two agricultural acidic soils. FEMS Microbiology Ecology. 108, 566-574.

Hatch, D., Trindade, H., Cardenas, L., Carneiro, J., Hawkins, J., Scholefield, D., Chadwick, D.2005. Laboratory study of the effects of two nitrification inhibitors on greenhouse gas emissions from a slurry-treated arable soil: impact of diurnal temperature cycle. Biology and Fertility of Soils. 41, 225-232.

He, J.Z., Shen, J.P., Zhang, L.M., Zhu, Y.G., Zheng, Y.M., Xu, M.G., Di, H.J., 2007. Quantitative analyses of the abundance and composition of ammoniaoxidizing bacteria and ammonia-oxidizing archaea of ammonia-oxidizing bacteria and ammoniaoxidizing archaea of a Chinese upland red soil under long-term fertilization practices. Environmental Microbiology. 9, 2364-2374.

Höfferle, Š., Nicol, G.W., Pal, L., Hacin, J., Prosser, J.I., Mandic-Mulec, I. 2010. Ammonia supply rate influences archaeal and bacterial ammonia oxidizers in a wet land soil vertical profile. FEMS Microbiology Ecology. 74, 302-315.
Jia, Z., Conard, R. 2009. Bacteria rather than Archaea dominate microbial ammoina oxidation in an agricultural soil. Environmental Microbiology. 11, 1658-1671.

Keeney, D.R,, Nelson, D.W. 1982. Nitrogen-inorganic forms. In: Page, A. L., Miller, R. H. Keeney, D. R.(Eds.), Methods of Soil Analysis, Part 2. Chemical and Microbiological Properties. Soil Science Society of America, Madison, Wisconsin USA. pp. 643-693.

Kurola, J., Salkinoja-Salonen, M., Aarnio, T., Hultman, J., Romantschuk, M. 2005. Activity, diversity and populationsize of ammonia-oxidising bacteria in oil-contaminated landfarming soil. FEMS Microbiol Lett. 250, 33-38.

Kleineidam, K., Kosmrlj, K., Kublik, S., Palmer, I., Pfab, H., Ruser, R., Fiedler, S., Schloter, M., 2011. Influence of the nitrification inhibitor 3,4-dimethylpyrazole phosphate (DMPP) on ammonia-oxidizing bacteria and archaea in rhizosphere and bulk soil. Chemosphere. 84(1), 182-186.

Leininger, S., Urich,T., Schloter, M., L. Schwark, Qi,J., Nicol, G.W., Prosser, J.I., Schuster, S.C., Schleper,C., 2006. Schleper, Archaea predominate among ammonia-oxidizing prokaryotes in soils. Nature. 442, 806-809.

Linzmeier, W., Gutser, R., Schmidhalter, U., 2001. Nitrous oxide emission from soil and from a nitrogen-15-labelled fertilizer with the new nitrification inhibitor 3,4-dimethylpyrazole phosphate (DMPP). Biology and Fertility of Soils. 34(2), 103-108.

Nicol, G.W., Leininger, S., Schleper, C., Prosser, J.I.,2008. The influence of soil $\mathrm{pH}$ on the diversity, abundance and transcriptional activity of ammonia oxidising archaea and bacteria, Environ Microbiol. 10, 2966-2978. 
O'Callaghan, M.E.M., Gerard, P.E., Carter, R., Lardner, U., Sarathchandra, G., Burch, A., Bell, N. 2010. Effect of the nitrification inhibitor dicyandiamide (DCD) on microbial communities in a pasture soil amended with bovine urine. Soil Biology and Biochemistry. 42, 1425-1436.

Rooney, D., Kennedy, N., Deering, L., Gleeson, D., Clipson, N. 2006. Effect of sheep urine deposition on the bacterial community structure in an acidic upland rassland soil. Applied and Environmental Microbiology. 72, 7231-7237.

Rotthauwe, J.H., Witzel, K.P., Liesack, W. 1997. The ammonia monooxygenase structural gene amoA as a functional marker: molecular fine-analysis of ntural ammonia-oxidizing populations. Applied and Environmental Microbiology. 63, 4704-4712.

Shen,J.P., Zhang, L.M., Zhu, Y.G., Zhang, J.B., He, J.Z. 2008. Abundance and composition of ammoniaoxidizing bacteria and ammonia-oxidizing archaea communities of an alkaline sandy loam, Environmental Microbiology. 10, 1601-161.

Singh, B.K., Nunan, N., Millard, P. 2009. Response of fungal, bacterial and ureolytic communities to synthetic sheep urine deposition in a grassland soil. FEMS Microbial Ecology. 70, 109-17.
Weiske, A., Benckiser, G., Ottow, J.C. 2001. Influence of the nitrification inhibitor 3,4-dimethylpyrazole (DMPP) in comparison to dicyandiamide (DCD) on nitrous oxide emissions, carbon dioxide fluxes and methane oxidation during 3-years of repeated applications in field experiments. Biology and Fertility of Soil. 34,109-117.

Zaman, M., Saggar, S., Blennerhassett, J.D., Singh, J. 2009. Effect of urea and nitrification inhibitors on $\mathrm{N}$ transformation, gaseous emissions of ammonia and nitrous oxide, pasture yield and $\mathrm{N}$ uptake in grazed pasture system. Soil Biology and Biochemistry. 41, 1270-1280.

Zerulla, W., Barth, T., Dressel, J., Erhardt, K., Horchler von Locquenghien, K., Wissemeir, A. 2001. 3,4-Dimethylpyrazole phosphate (DMPP)-a new nitrification inhibitor for agriculture and horticulture. Biology and Fertility of Soils. 34, 79-84. 